\title{
Synthesis and in vitro cytotoxicity of acetylated 3-fluoro, 4-fluoro and 3,4-difluoro analogs of D-glucosamine and D-galactosamine
}

\author{
Štěpán Horník ${ }^{1}$, Lucie Červenková Št’astná ${ }^{1}$, Petra Cuřínová ${ }^{1}$, Jan Sýkora ${ }^{1}$, \\ Kateřina Káňová ${ }^{2}$, Roman Hrstka ${ }^{2}$, Ivana Císařová ${ }^{3}$, Martin Dračínský ${ }^{4}$ \\ and Jindřich Karban ${ }^{* 1}$
}

\author{
Full Research Paper \\ Address: \\ ${ }^{1}$ Institute of Chemical Process Fundamentals of the CAS, Rozvojová \\ 135, 16502 Praha, Czech Republic, ${ }^{2}$ Regional Centre for Applied and \\ Molecular Oncology, Masaryk Memorial Cancer Institute, Žlutý kopec \\ 7, 65653 Brno, Czech Republic, ${ }^{3}$ Department of Inorganic Chemistry, \\ Charles University, Hlavova 2030, 12843 Praha 2, Czech Republic \\ and ${ }^{4}$ Institute of Organic Chemistry and Biochemistry, Flemingovo \\ nám. 2, 16610 Praha 6, Czech Republic \\ Email: \\ Jindřich Karban* - karban@icpf.cas.cz \\ * Corresponding author \\ Keywords: \\ amino sugars; cytotoxicity; fluorinated carbohydrates; fluorine; \\ hexosamines \\ Beilstein J. Org. Chem. 2016, 12, 750-759. \\ doi:10.3762/bjoc. 12.75 \\ Received: 08 February 2016 \\ Accepted: 30 March 2016 \\ Published: 20 April 2016 \\ Associate Editor: S. Flitsch \\ (c) 2016 Horník et al; licensee Beilstein-Institut. \\ License and terms: see end of document.
}

\begin{abstract}
Background: Derivatives of D-glucosamine and D-galactosamine represent an important family of the cell surface glycan components and their fluorinated analogs found use as metabolic inhibitors of complex glycan biosynthesis, or as probes for the study of protein-carbohydrate interactions. This work is focused on the synthesis of acetylated 3-deoxy-3-fluoro, 4-deoxy-4-fluoro and 3,4dideoxy-3,4-difluoro analogs of D-glucosamine and D-galactosamine via 1,6-anhydrohexopyranose chemistry. Moreover, the cytotoxicity of the target compounds towards selected cancer cells is determined.
\end{abstract}

Results: Introduction of fluorine at C-3 was achieved by the reaction of 1,6-anhydro-2-azido-2-deoxy-4- $O$-benzyl- $\beta$-D-glucopyranose or its 4-fluoro analog with DAST. The retention of configuration in this reaction is discussed. Fluorine at C-4 was installed by the reaction of 1,6:2,3-dianhydro- $\beta$-D-talopyranose with DAST, or by fluoridolysis of 1,6:3,4-dianhydro-2-azido- $\beta$-D-galactopyranose with $\mathrm{KHF}_{2}$. The amino group was introduced and masked as an azide in the synthesis. The 1-O-deacetylated 3-fluoro and 4-fluoro analogs of acetylated D-galactosamine inhibited proliferation of the human prostate cancer cell line PC-3 more than cisplatin and 5-fluorouracil ( $\mathrm{IC}_{50} 28 \pm 3 \mu \mathrm{M}$ and $54 \pm 5 \mu \mathrm{M}$, respectively). 
Conclusion: A complete series of acetylated 3-fluoro, 4-fluoro and 3,4-difluoro analogs of D-glucosamine and D-galactosamine is now accessible by 1,6-anhydrohexopyranose chemistry. Intermediate fluorinated 1,6-anhydro-2-azido-hexopyranoses have potential as synthons in oligosaccharide assembly.

\section{Introduction}

Derivatives of D-glucosamine $(\mathrm{GlcN})$ and D-galactosamine (GalN) are essential amino sugar components of glycans in glycoproteins, glycolipids and proteoglycans. As such, they participate in functions performed by cell-surface glycans including cell adhesion and signaling [1]. Unnatural analogs of these amino sugars prepared by a selective replacement of a hydroxy group by fluorine have proved valuable tools to perturb glycan and glycosaminoglycan biosynthesis [2,3], to inhibit amino sugars processing enzymes [4,5], to probe interactions of amino sugars with their target enzymes and lectins [6,7], or to increase the hydrolytic stability of the glycosidic bond in amino sugar glycosides [8,9]. For example, acetylated 4-fluoro analogs of D-glucosamines 1-3, D-galactosamine 4, and 6-fluoro-Dgalactosamine 9 (Figure 1) acted as metabolic inhibitors of the biosynthesis of cell-surface $\mathrm{O}$ - and N-linked glycans (including their lactosamine and sialyl Lewis ${ }^{\mathrm{X}}$ terminal epitopes) $[2,3,10,11]$, and glycosaminoglycans [3]. The resulting disruption of protein-(glycosamino)glycan interactions had important biomedical consequences such as reduced selectin-mediated tumor cell adhesion [12,13], suppressed selectin-mediated leukocyte migration $[11,14,15]$, reduced angiogenesis [3], or inhibition of tumor growth by decreased galectin-mediated antitumor T cell apoptosis [16].

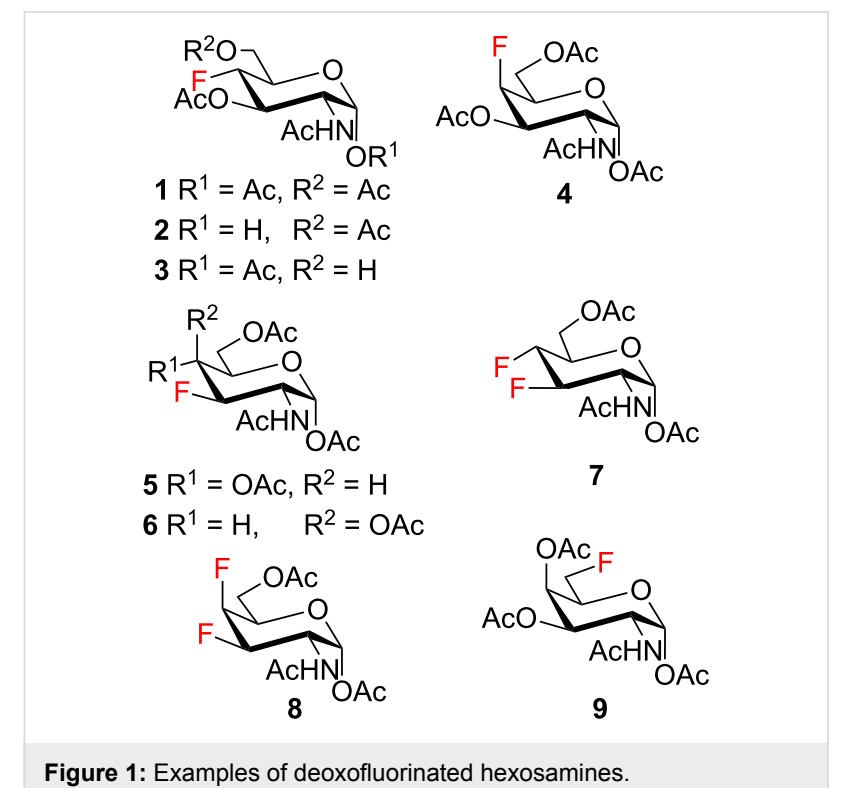

Figure 1: Examples of deoxofluorinated hexosamines.

Some acetylated fluoro hexosamines also displayed antiproliferative properties in vitro [17]. For example, 3- and 4-fluoro-Dglucosamine analogs 5 [18] and 1 [19], and 4-fluoro-D- galactosamine analog 4 [19] (Figure 1), inhibited the growth of murine L1210 leukemia cells in micromolar range $\left(\mathrm{IC}_{50} 27-35 \mu \mathrm{M}\right)$. Compound 5 also inhibited the proliferation of the human pancreatic cancer cell line KP1-NL $\left(\mathrm{IC}_{50} 30 \mu \mathrm{M}\right)$ [20] and 4-fluoro-D-glucosamine analogs $\mathbf{1}$ and $\mathbf{2}$ were reported to inhibit the proliferation of the human prostate cancer cell line PC-3 ( $\mathrm{IC}_{50} 61 \mu \mathrm{m}$ for 2) [2].

The remarkable ability of acetylated fluoro analogs of GlcNAc and GalNAc to perturb the (glycosamino)glycan biosynthesis and their antiproliferative properties aroused our interest in developing a methodology for the preparation of a complete series of acetylated 3-fluoro, 4-fluoro-, and 3,4-difluoro analogs 1, 4-8 (Figure 1) including previously unknown members of this class of hexosamine mimics: acetylated 3-fluoro-D-GalNAc 6, 3,4-difluoro-D-GlcNAc 7 and 3,4-difluoro-D-GalNAc 8, as well as 3-fluoro-D-GlcNAc 5, in which case the reported synthesis was troublesome and low-yielding [20]. To carry out the synthesis, flexible synthetic methods for the stereoselective introduction of fluorine at one or more designated positions of the hexosamine skeleton are necessary. The elaborated chemistry of 1,6-anhydrohexopyranose derivatives is suitable for this purpose [21-23]. Building on previous results from our [24] and other groups [25-28], we designed an approach based on stereoselective introduction of an azide as a masked amine group at $\mathrm{C}-2$, and fluorine at C-3 and C-4 by nucleophilic displacement. Resulting 3-fluoro, 4-fluoro, and 3,4-difluoro analogs of 2-azido-1,6-anhydrohexopyranoses were then converted into the target fluoro analogs of D-glucosamine and D-galactosamine (Scheme 1). Dual protection of the anomeric and primary hydroxy groups in the form of the 1,6-anhydro bridge reduced the number of protecting groups, and the rigid bicyclic skeleton of 1,6-anhydrohexopyranoses enabled a high degree of regioand stereocontrol necessary for the introduction of heteroatomic substituents at C-2, C-3, and C-4. The synthesis of the analogs 6-8 has not yet been reported to our knowledge, while the synthesis of 1, $\mathbf{4}$ and $\mathbf{5}$ represents an alternative to the published procedures $[2,20,29]$. Herein we also report on the cytotoxicity of prepared fluoro analogs in the human ovarian cancer A2780

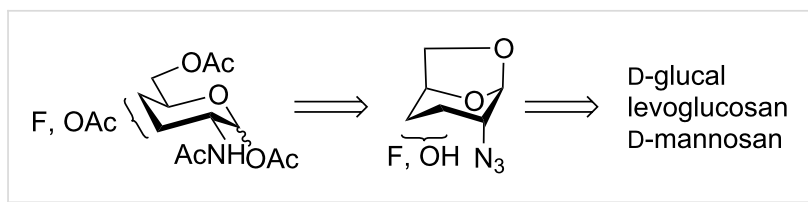

Scheme 1: Retrosynthetic plan. 
and prostate cancer PC-3 cell lines. Preliminary results for the synthesis of compounds $\mathbf{5}$ and $\mathbf{6}$ were communicated earlier in a letter [30].

\section{Results and Discussion Synthesis}

The synthesis commenced with the introduction of an azide at the $2 \alpha$-position of the 1,6-anhydropyranose skeleton by nucleophilic cleavage of a $2 \beta, 3 \beta$-epoxide or the displacement of the C-2 $\beta$ triflate ester using mainly a combination of published procedures (Scheme 2). 2-Azido alcohols 11, 12 and 15 were obtained from 1,6:2,3-dianhydro-4-O-benzyl- $\beta$-D-mannopyranose (10, one of the Černý epoxides available from D-glucal [31-33] or levoglucosan [34]). Regioselective azidolysis [21,35,36] of 10 yielded 2-azido alcohol 11 which was converted to $\mathbf{1 2}$ by benzoylation at O-3 and debenzylation at O-4. To prevent azide reduction, oxidative debenzylation [24] was applied instead of the more common hydrogenation. Debenzylation of $\mathbf{1 0}$ gave dianhydro derivative $\mathbf{1 3}$ [34,37] (available also directly from D-glucal [31,33] or from levoglucosan [38]) which was converted to 14 by Latrell-Dax inversion at C-4 [39]. $O$-Benzylation [40] of $\mathbf{1 4}$ followed by azidolysis [41] furnished $\mathbf{1 5}$ 2-Azido-3,4-epoxide $\mathbf{1 8}$ was prepared from readily available [42] 2,3-isopropylidene-D-mannosan (16) in five steps (Scheme 2). Tosylation of $\mathbf{1 6}$ [43], followed by hydrolysis of the benzylidene acetal [44] and oxirane ring closure [45] at C-4 delivered 1,6:3,4-dianhydro derivative 17. Formation of the triflate ester and azidolysis furnished 1,6:3,4-dianhydro-2-azido

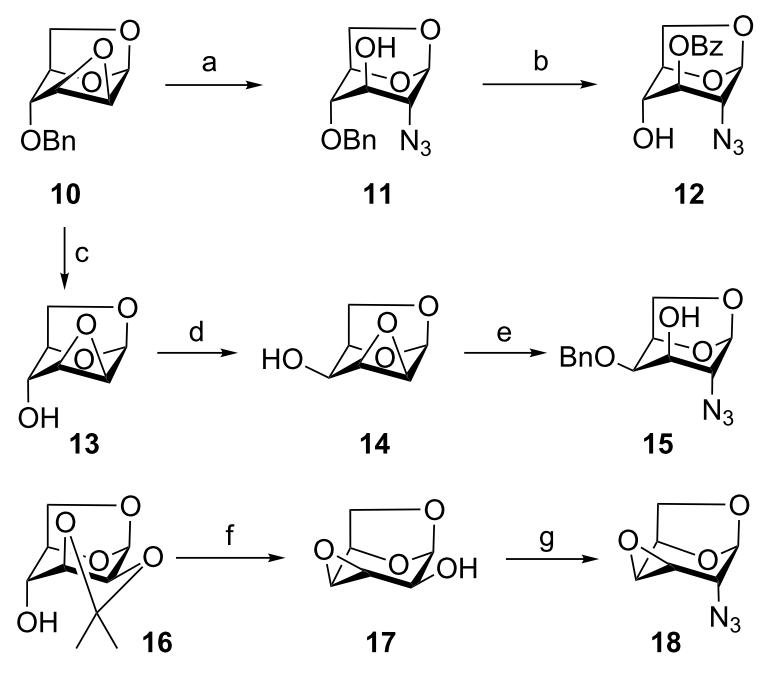

Scheme 2: Preparation of starting 2-azido compounds. Reagents and conditions: (a) $\mathrm{NaN}_{3}, \mathrm{NH}_{4} \mathrm{Cl}, \mathrm{MeOC}_{2} \mathrm{H}_{4} \mathrm{OH}, 79 \%$; (b) i) $\mathrm{BzCl}$, py; ii) $\mathrm{NaBrO}_{3}, \mathrm{Na}_{2} \mathrm{~S}_{2} \mathrm{O}_{4}, \mathrm{AcOEt}, \mathrm{H}_{2} \mathrm{O}, 47 \%$ over 2 steps; (c) $\mathrm{Pd} / \mathrm{C}, \mathrm{H}_{2}$, $\mathrm{EtOH}, 96 \%$; (d) $\mathrm{Tf}_{2} \mathrm{O}$, then (Bu) ${ }_{4} \mathrm{NNO}_{2}, 69 \%$; (e) (i) $\mathrm{NaH}, \mathrm{BnBr}, \mathrm{THF}$, $79 \%$; (ii) $\mathrm{LiN}_{3}, \mathrm{NH}_{4} \mathrm{Cl}, \mathrm{MeOC}_{2} \mathrm{H}_{4} \mathrm{OH}, 100{ }^{\circ} \mathrm{C}, 81 \%$; (f) (i) $\mathrm{TsCl}, \mathrm{py}$, (ii) $\mathrm{AcOH}, \mathrm{H}_{2} \mathrm{O}$; (iii) IRA $410\left(\mathrm{OH}^{-}\right), \mathrm{MeOH}, 78 \%$ over 3 steps; (g) (i) $\mathrm{Tf}_{2} \mathrm{O}$, py, $\mathrm{CH}_{2} \mathrm{Cl}_{2}$; (ii) $\mathrm{LiN}_{3}$, DMF, $82 \%$ over 2 steps. derivative 18. Lithium azide was found superior to sodium azide in conversion of the triflate to the azide $\mathbf{1 8}$, and the yield of 18 increased from $48 \%$ reported earlier [46] to $82 \%$.

The synthesis of mono- and difluoro analogs of 2-azido-2deoxy-1,6-anhydrohexopyranoses, which are key intermediates, is shown in Scheme 3. We first explored the reactions of azido alcohols 11, 12 and $\mathbf{1 5}$ (Scheme 3) with diethylaminosulfur trifluoride (DAST) to achieve the introduction of a nucleophilic fluorine atom. Reaction of $\mathbf{1 1}$ with DAST using a minor modification of the reported procedure [28] provided the D-glucoconfigured 3-fluoro-derivative 19 (Scheme 3) with clean retention of configuration. To prepare the D-galacto-configured analog of $\mathbf{1 9}$, deoxofluorination of $\mathbf{1 5}$ by reaction with DAST in benzene at $75^{\circ} \mathrm{C}$ (conditions used for fluorination of 11), or in dichloromethane at $\mathrm{rt}$ was attempted. Disappointingly, only unreacted 15 was recovered. A very slow formation of several unidentified fluorine-containing compounds ( ${ }^{19} \mathrm{~F}$ NMR) was observed on prolonged reaction times. Oxidative debenzylation of 19 gave fluorhydrin $\mathbf{2 0}$ which was subjected to epimerization at C-4 by Latrell-Dax inversion to furnish 2-azido-3-fluoro compound $\mathbf{2 1}$ with the desired D-galacto configuration (Scheme 3). The geminal fluorine-carbon coupling value ${ }^{2} J_{\mathrm{C} 4, \mathrm{~F}}=17.7 \mathrm{~Hz}$ in $\mathbf{2 1}$ is characteristic for a gauche relationship between the $\mathrm{C} 3-\mathrm{F}$ and $\mathrm{C} 4-\mathrm{O}$ bonds whereas ${ }^{2} J_{\mathrm{C} 4, \mathrm{~F}}=31.5 \mathrm{~Hz}$ in $\mathbf{2 0}$ is consistent with an antiperiplanar arrangement. The inversion at $\mathrm{C}-4$ is also manifested by an increase in the ${ }^{3} J_{\mathrm{H} 4, \mathrm{H} 3 / 5}$ values $(1.7 \rightarrow 4.5 \mathrm{~Hz})$ together with an increase of the ${ }^{3} J_{\mathrm{F}, \mathrm{H} 4}$ coupling $(13.9 \rightarrow 26.4 \mathrm{~Hz})$.

An attempt to introduce fluorine at C-4 on reaction of $\mathbf{1 2}$ with DAST furnished orthoester $\mathbf{2 5}$ instead of the desired 4-fluoro derivative. The structure of orthoester $\mathbf{2 5}$ was confirmed by single crystal X-ray analysis. The formation of $\mathbf{2 5}$ resulted from an intramolecular displacement of the unstable alkoxysulfur intermediate $\mathbf{2 3}$ with the oxygen of the benzoyl group and a subsequent reaction of the salt $\mathbf{2 4}$ with methanol upon quenching. A similar participation of a vicinal $O$-acetyl protecting group on reaction with DAST leading to the formation of an orthoacetate was reported [47]. Reaction of fluorohydrin 20 with DAST proceeded with inversion at C-4 giving 3,4-difluoro analog 22. The D-galacto configuration of 22 was manifested by the values of the vicinal coupling constants ${ }^{3} J_{\mathrm{H} 2, \mathrm{H} 3}=1.6 \mathrm{~Hz}$ and ${ }^{3} J_{\mathrm{H} 3, \mathrm{H} 4}=4.5 \mathrm{~Hz}$, and the large value of ${ }^{2} J_{\mathrm{C} 5, \mathrm{~F} 4}=27.2 \mathrm{~Hz}$ confirmed the equatorial position of fluorine at C-4.

Cleavage of the oxirane ring in $\mathbf{1 8}$ on reaction with $\mathrm{KHF}_{2}$ in ethylene glycol $[48,49]$ furnished the 4-fluoro derivative $\mathbf{2 6}$ (Scheme 3). The moderate yield of $26(40-60 \%)$ can be attributed to the formation of the 4-O-(2-hydroxyethyl) derivative 
<smiles>COC1C2COCC(CO2)C1N</smiles>

11<smiles>CC1C(N)C2COC(O2)C1OCc1ccccc1</smiles>

19<smiles>CC(C)C1OC2COC(O2)C1[NH]</smiles>

20<smiles>NC1C2COC(O2)C1O</smiles>

21

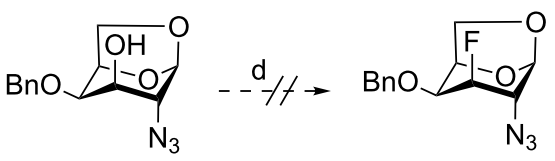

15

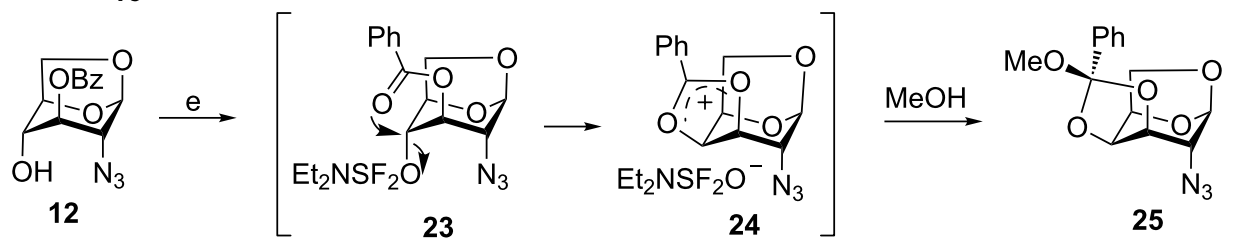

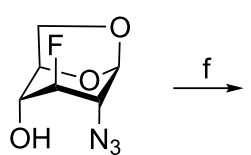

20<smiles>NC1C2COC(O2)C1F</smiles>

22<smiles>CC1C2OC3OC1C(N)C3O2</smiles>

18

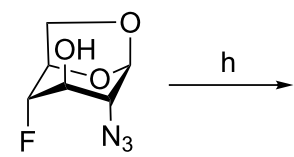

26

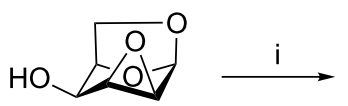

14<smiles>NC1C2OCC(O2)C1O</smiles>

26<smiles>NC1C2OCC(O2)C1F</smiles>

28<smiles></smiles>

$\mathrm{HO}$

27<smiles>FNC1C(F)C2COC(O2)C1F</smiles>

29

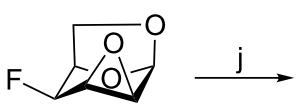

30

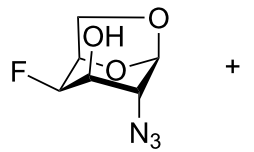

31

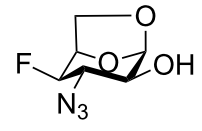

32

Scheme 3: Preparation of mono and difluoro analogs of 2-azido-2-deoxy-1,6-anhydro- $\beta$-D-gluco- and galactopyranoses. Reagents and conditions: (a) DAST, benzene, $75-81^{\circ} \mathrm{C}, 88 \%$; (b) $\mathrm{NaBrO}_{3}, \mathrm{Na}_{2} \mathrm{~S}_{2} \mathrm{O}_{4}$, EtOAc, $\mathrm{H}_{2} \mathrm{O}, 75 \%$; (c) $\mathrm{Tf}_{2} \mathrm{O}$, py, $\mathrm{CH}_{2} \mathrm{Cl}_{2}$; then $(\mathrm{Bu})_{4} \mathrm{NNO}_{2}$, DMF, 67\%; (d) DAST, benzene, $75-81{ }^{\circ} \mathrm{C}$; or DAST, $\mathrm{CH}_{2} \mathrm{Cl}_{2},-25^{\circ} \mathrm{C}$ to rt; (e) DAST, $\mathrm{CH}_{2} \mathrm{Cl}_{2},-25{ }^{\circ} \mathrm{C}$ to rt, $78 \%$; (f) DAST, $\mathrm{CH}_{2} \mathrm{Cl}_{2},-25{ }^{\circ} \mathrm{C}$ to rt, $65 \%$; (g) $\mathrm{KHF}_{2}, \mathrm{C}_{2} \mathrm{H}_{4}(\mathrm{OH})_{2}$, $175{ }^{\circ} \mathrm{C}, 40-60 \%$ (26); (h) DAST, benzene, $75-81^{\circ} \mathrm{C}, 46 \%$ (28), $12 \%$ (29); (i) DAST, $\mathrm{CH}_{2} \mathrm{Cl}_{2},-50{ }^{\circ} \mathrm{C}$ to rt, $52 \%$, (j) $\mathrm{LiN}_{3}, \mathrm{NH}_{4} \mathrm{Cl}, \mathrm{MeOC}_{2} \mathrm{H}_{4} \mathrm{OH}$, $100{ }^{\circ} \mathrm{C}, 74 \%(31)$

27 arising from solvent participation, and to a partial decomposition (indicated by TLC) at high temperatures necessary for the reaction to proceed. The low values of the vicinal coupling constant ${ }^{3} J_{\mathrm{H} 3, \mathrm{H} 4}=2.0 \mathrm{~Hz}$ and the large value of the geminal coupling constant ${ }^{2} J_{\mathrm{C} 3, \mathrm{~F}}=29.6 \mathrm{~Hz}$ evidenced a trans-diaxial relationship between the C-3 and C-4 substituents in $\mathbf{2 6}$. The reaction of fluorohydrin 26 with DAST in benzene under heating afforded, as the main product, 3,4-difluoro-D-gluco analog 28 (46\%), and the rearranged 2,6-anhydro compound 29 (12\%) as a side product. Products $\mathbf{2 8}$ and $\mathbf{2 9}$ can be separated by careful chromatography and their structures were verified by single crystal X-ray analysis.

Since fluorination of $\mathbf{1 2}$ with DAST failed to introduce fluorine at $C-4 \beta$ due to formation of orthoester 25 , the reaction of 1,6:2,3-dianhydro- $\beta$-D-talopyranose 14 with DAST was utilized to give 1,6:2,3-dianhydro-4-deoxy-4-fluoro- $\beta$-D-talopyranose (30) with retention of the configuration at C-4 [39]. Azidolysis 
of the oxirane ring in the reaction with lithium azide furnished 2-azido derivative 31. Although nucleophilic cleavage of a three-membered ring annulated to the 1,6-anhydrohexopyranose skeleton usually occurs solely in trans-diaxial fashion [50], formation of the trans-diequatorial side-product $\mathbf{3 2}$ in ca. $8 \%$ was observed in NMR spectra. The desired D-galactoconfigured 2-azido derivative $\mathbf{3 1}$ was separated from $\mathbf{3 2}$ by crystallization in $74 \%$ yield. The D-galacto configuration of $\mathbf{3 1}$ is evidenced by the vicinal coupling values ${ }^{3} J_{\mathrm{H} 4, \mathrm{H} 3 / 5}=4.5 \mathrm{~Hz}$ and the long range coupling between equatorial protons $\mathrm{H}-1$, $\mathrm{H}-3$, and $\mathrm{H}-5\left({ }^{4} J_{\mathrm{H} 3, \mathrm{H} 1 / 5}=1.4 \mathrm{~Hz}\right)$.

The reaction of the D-gluco-configured 3-hydroxy derivatives 11, and 26 with DAST, and the previously reported reactions of D-gluco-configured 3-hydroxy derivatives 33 [26], 34 [27], and 35 [25] (Scheme 4) with DAST are an important means of obtaining 3-deoxy-3-fluoro derivatives of D-gluco-configured aldohexopyranoses which are difficult to prepare otherwise. These reactions characteristically proceed with a clean retention of configuration which can be explained by an anchimeric assistance of the trans-diaxially positioned (with respect to $\mathrm{C} 3-\mathrm{OH})$ polar groups at $\mathrm{C}-2$ or $\mathrm{C}-4$, or by an internal fluorine attack as in $\mathrm{S}_{\mathrm{N}} \mathrm{i}$ substitution. A simple $\mathrm{S}_{\mathrm{N}} 2$ displacement leading to configurational inversion is probably suppressed by the steric effects of the axially positioned groups at C-2 and $\mathrm{C}-4$, and repulsive effects of their aligned dipoles [51]. Compounds 11, and 33-35, possess a trans-diaxially positioned benzyloxy group at $\mathrm{C}-4$ capable of participation through an oxiranium intermediate species (Scheme 4A) [52-54]. The formation of the rearranged difluoride 29 from alcohol 26 (Scheme 3) suggests an anchimeric assistance of the vicinal C-2 azido group. Although rare, azide participation was postulated before [52]. The main product $\mathbf{2 8}$ and rearranged difluoride $\mathbf{2 9}$ can arise from the same intermediate species 39 (Scheme 4B, pathways a and $b$, respectively). Compound 19 can, in principle, be also formed from 11 through azide participation (not shown). In such a case the reaction is unexpectedly sensitive to minor steric alterations of the substrate because the C-4 epimer 15 (Scheme 3) did not react. An internal fluorine attack from the $\beta$-face of the tetrahydropyran ring through a concerted (Scheme 4C) or contact ion-pair (Scheme 4D) $\mathrm{S}_{\mathrm{N}} \mathrm{i}$ mechanism cannot be ruled out $[55,56]$ because the bulky $\mathrm{Et}_{2} \mathrm{NSF}_{2} \mathrm{O}$ substituent at $\mathrm{C}-3$ might force the substrate to adopt boat $B_{3, \mathrm{O}}$ conformation [57] bringing the C-2, C-3 and C-4 substituents into a trans-equatorial arrangement unfavorable for anchimeric assistance.

With the D-gluco- and D-galacto-configured deoxofluoro derivatives of 2-azido-1,6-anhydrohexopyranoses in hand, we examined their conversion to the target acetylated hexosamine analogs. Initially, compound $\mathbf{1 9}$ was hydrogenated $(\mathrm{Pd} / \mathrm{C})$ and acetylated to afford acetamide $\mathbf{4 0}$ in modest yield (37\%). Sulfuric acid-catalyzed [35] cleavage of the internal acetal with acetic anhydride gave a mixture containing 1,2-oxazoline $\mathbf{4 1}$ as the main product (Scheme 5). The structure of oxazoline 41 was confirmed by single crystal X-ray diffraction analysis which

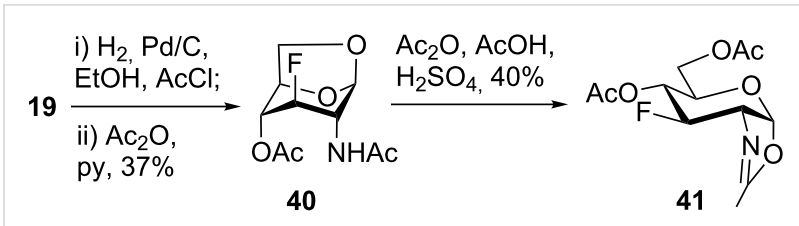

Scheme 5: Formation of oxazoline 41 from 19
A)

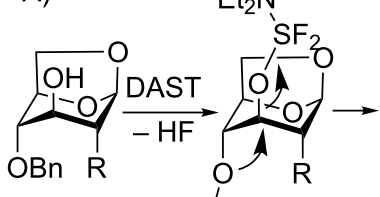

$11 \mathrm{R}=\mathrm{N}_{3} \quad \mathrm{Bn}$

$33 \mathrm{R}=\mathrm{OBn}$

$34 \mathrm{R}=\mathrm{F}$

$35 \mathrm{R}=\mathrm{H}$

C)
B)

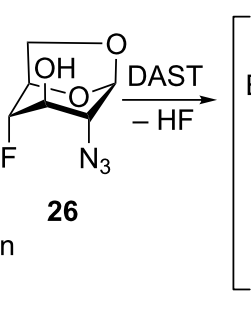

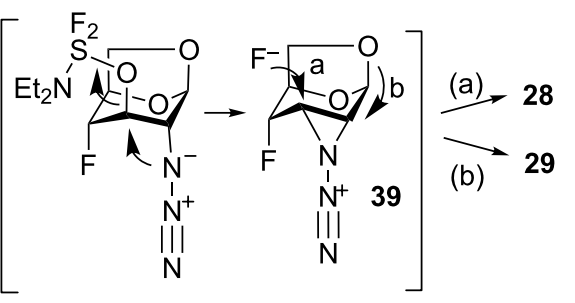

D)

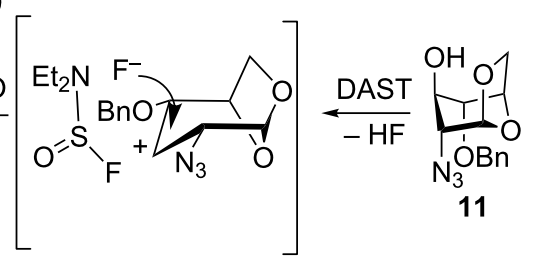

Scheme 4: Suggested mechanisms for deoxofluorination at C-3 of 1,6-anhydro- $\beta$-D-glucohexopyranose derivatives. A) participation of the O-benzyl group; B) participation of the azide group; C) internal fluorine attack, concerted mechanism; D) internal fluorine attack, contact ion pair mechanism. 
also confirmed the retention of configuration during the preceding fluorine introduction.

To prevent oxazoline formation, the order of reactions was reversed, and triethylsilyl triflate (TESOTf)-catalyzed [58] acetolysis of the 1,6-anhydro bridge in $\mathbf{1 9}$ gave $\mathbf{4 2}$ (Table 1) as a mixture of anomers from which the $\alpha$-anomer crystallized.
TESOTf as a catalyst for acetolysis gave better results than sulfuric acid in terms of product purity. Hydrogenolysis of $\mathbf{4 2}$ on palladium in ethanol/ $\mathrm{HCl}$ followed by acetylation of the amino group furnished the target acetylated 3-fluoro-D-GlcNAc 5 as a chromatographically separable mixture of anomers (Table 1). Addition of $\mathrm{HCl}$ was found necessary to effect a clean hydrogenolytic removal of the $O$-benzyl group in $\mathbf{4 2}$. The

Table 1: Acetolysis of the fluorine-containing intermediates and hydrogenation.

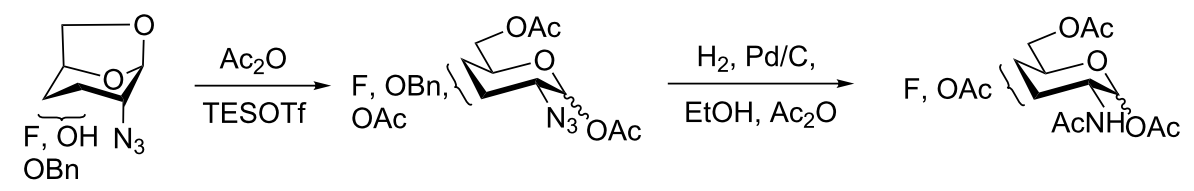

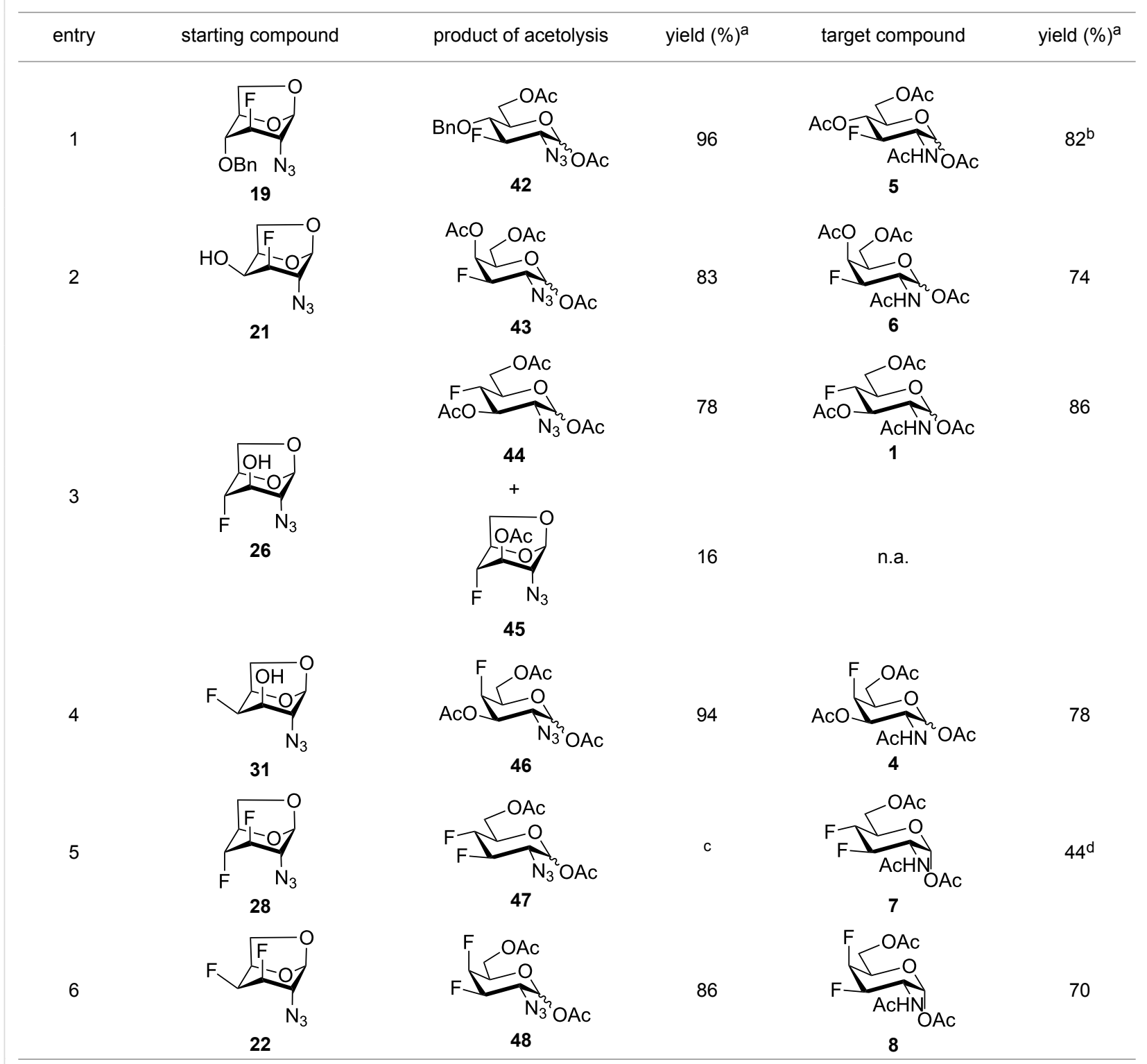

alsolated yield; ${ }^{\mathrm{b}} \mathrm{H}_{2}, \mathrm{Pd} / \mathrm{C}, \mathrm{EtOH}, \mathrm{AcCl}$, then $\mathrm{Ac}_{2} \mathrm{O}$, py was used for hydrogenation of $\mathbf{4 2} ;{ }^{\mathrm{c}} \mathbf{4 7}$ was not isolated as pure compound, see text; ${ }^{\mathrm{d}} \mathrm{Overall}$ from 28; n.a. - not available. 
D-gluco configuration of $\mathbf{4 2}$ and $\mathbf{5}$ was reflected in the large values of ${ }^{3} J_{\mathrm{H} 3, \mathrm{H} 2 / 4}(7.6-10.2 \mathrm{~Hz})$, and the chair inversion accompanying the cleavage of the 1,6-anhydro bridge $\left({ }^{1} C_{4} \rightarrow{ }^{4} C_{1}\right)$ in a decrease of the geminal fluorine-carbon coupling value ${ }^{2} J_{\mathrm{C} 4, \mathrm{~F}}(31.5 \mathrm{~Hz}$ in $\mathbf{4 0} \rightarrow 18.4 \mathrm{~Hz}$ in $\mathbf{5}$ ( $\alpha$-anomer)) [59]. ${ }^{1} \mathrm{H}$ and ${ }^{13} \mathrm{C}$ NMR spectra of 5 reported in [20] are comparable with our data for the $\alpha$-anomer $(\mathbf{5 \alpha})$. A discrepancy in the values of specific optical rotation $[\alpha]_{\mathrm{D}}^{20}$ (reported $+10^{\circ},+81^{\circ}$ obtained by us) can be explained assuming that the value for the $\beta$-anomer (5及) was reported in [20]. Our synthesis of $\mathbf{5}$ is more practical (55\% from 10 in 3 steps) than the earlier preparations which were reported troublesome owing to low yields ( $28 \%$ and $10 \%$, respectively) of the key fluorination step $[18,20]$.

For the remaining fluoro derivatives of 1,6-anhydro-2-azidohexopyranoses, TESOTf-catalyzed acetolysis and subsequent hydrogenation $(\mathrm{Pd} / \mathrm{C}$ in a mixture of ethanol and acetic anhydride) was applied to obtain the target acetylated fluoro analogs (Table 1). Compound 21 was acetolyzed to 43 which was obtained as a mixture of anomers and characterized by NMR and finally hydrogenated to furnish acetylated 3-fluoroGalNAc 6 isolated as a separable mixture of anomers. The D-galacto configuration of 6 is manifested by the lower ${ }^{3} J_{\mathrm{H} 3, \mathrm{H} 4}$ coupling value $(3.4 \mathrm{~Hz}, \alpha$-anomer) in comparison with that of its C-4 epimer $5(8.6 \mathrm{~Hz}, \alpha$-anomer). Acetolysis of the internal acetal in $\mathbf{2 6}$ proceeded more slowly and beside the desired product 44 (78\% yield), 3-O-acetyl derivative 45, in which the 1,6anhydro bridge remained intact, was also isolated. Hydrogenation of $\mathbf{4 4}$ furnished the known acetylated 4-fluoro-D-GlcNAc 1 [2]. The large values of the vicinal coupling constants ${ }^{3} J_{\mathrm{H} 3, \mathrm{H} 2 / 4}$ and ${ }^{3} J_{\mathrm{H} 4, \mathrm{H} 5}(8.9-11.1 \mathrm{~Hz})$ confirmed the D-gluco configuration of $\mathbf{1}$ and the chair inversion when going from $\mathbf{2 6}$ to $\mathbf{1}$, which was also manifested by a decrease in the geminal coupling constant ${ }^{2} J_{\mathrm{C} 3, \mathrm{~F}}(29.6 \rightarrow 18.9 \mathrm{~Hz}, \alpha$-anomer $)$. Acetolysis and subsequent hydrogenation of $\mathbf{3 1}$ provided the known peracetylated 4-deoxy-4-fluoro-D-galactosamine 4 [29]. The chair inversion of the tetrahydropyran ring associated with the cleavage of the 1,6-anhydro bridge is indicated by the increase in the coupling value ${ }^{3} J_{\mathrm{H} 2 \mathrm{H} 3}(1.4 \rightarrow 11.6 \mathrm{~Hz})$ and decrease in the coupling value ${ }^{2} J_{\mathrm{C} 5, \mathrm{~F}}(27.4 \rightarrow 18.4 \mathrm{~Hz})$ when going from 31 to 4 ( $\alpha$-anomer). Acetolysis of $\mathbf{2 8}$ afforded diacetate $\mathbf{4 7}$ containing chromatographically inseparable impurities (NMR). They were removed in the next hydrogenation step to yield the peracetylated 3,4-difluoro analog of D-glucosamine 7 isolated as an $\alpha$-anomer in $44 \%$ yield from $\mathbf{2 8}$. The D-gluco configuration of 7 is reflected in the large values of the vicinal coupling constants ${ }^{3} J_{\mathrm{H} 2, \mathrm{H} 3}=10.5 \mathrm{~Hz},{ }^{3} J_{\mathrm{H} 3, \mathrm{H} 4}=8.2 \mathrm{~Hz}$, and ${ }^{3} J_{\mathrm{H} 4, \mathrm{H} 5}=9.8 \mathrm{~Hz}$. Acetolysis of $\mathbf{2 2}$ gave diacetate $\mathbf{4 8}$ as a separable mixture of anomers. Hydrogenation of the $\alpha$-anomer furnished the peracetylated 3,4-difluoro analog of D-galactosamine 8 . The D-galacto configuration of $\mathbf{8}$ was confirmed by an increase in the value of ${ }^{3} J_{\mathrm{H} 2, \mathrm{H} 3}(1.6 \rightarrow 11.1 \mathrm{~Hz})$, a decrease in the value of ${ }^{2} J_{\mathrm{C} 5, \mathrm{~F} 4}(27.2 \rightarrow 18.3 \mathrm{~Hz})$, and an increase of ${ }^{3} J_{\mathrm{H} 3, \mathrm{~F} 4}$ coupling $(4.3 \rightarrow 26.0 \mathrm{~Hz})$ between 22 and 8 .

To study the influence of 1-O-deacetylation on the cytotoxicity, the monofluorinated analogs 1, and 4-6 were subjected to anomeric deacetylation (Scheme 6). Compound 5 provided 1-Odeacetylated product 49 by treatment with $\mathrm{BnNH}_{2}$ in THF. Since acetylated 4-fluoro-D-GlcNAc 1 under these conditions did not react cleanly, we used piperidine-promoted [60] deacetylation to prepare 2 in $74 \%$ yield. Similarly, acetylated 4-fluoro-D-GalNAc 4 gave $\mathbf{5 0}$ in $60 \%$ yield. The attempted anomeric deacetylation of 3-fluoro-D-GalNAc 6 by treatment with piperidine followed by chromatography gave a fraction containing an inseparable side-product in addition to the expected deacetylated product $\mathbf{5 1}$. The side-product showed no fluorine resonance in ${ }^{19} \mathrm{~F}$ NMR and its molecular formula $\mathrm{C}_{17} \mathrm{H}_{28} \mathrm{~N}_{2} \mathrm{O}_{7}$ assigned by LC-HRMS corresponded to a formal displacement of fluorine by piperidine, leading probably to compound 53. When pure 51 (prepared by another method, see below) was reacted with excess piperidine, high resolution ESIMS analysis of the reaction detected transient formation of an adduct ion corresponding to a supposed intermediate enal $\mathbf{5 2}$ (Scheme 6), while the adduct ion corresponding to $\mathbf{5 3}$ was the final product (see Supporting Information File 1). Presumably, piperidine as a relatively strong base effected dehydrofluorination of $\mathbf{5 1}$ to enal $\mathbf{5 2}$ which then added piperidine to give $\mathbf{5 3}$ as a byproduct (Scheme 6). To avoid the action of basic amines, a silica gel mediated anomeric deacetylation, recommended for 2 -aminosugars [61], was tried. The reaction proceeded extremely slowly with our substrate $\mathbf{6}$ and the product 51 was obtained in only $40 \%$ yield after chromatography and recrystallization.

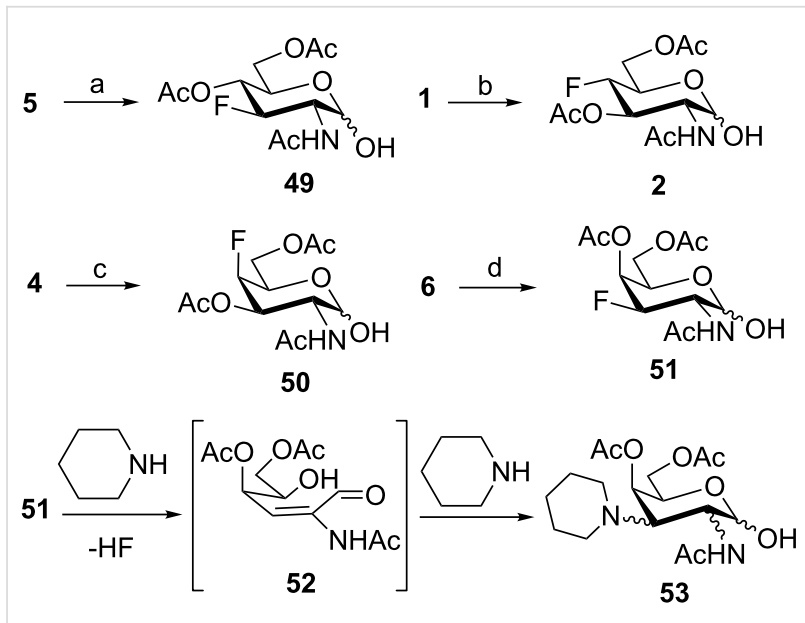

Scheme 6: 1-O-Deacetylation of monofluorinated hexosamines. Reagents and conditions: (a) $\mathrm{BnNH}_{2}$, THF, $62 \%$; (b) $\mathrm{C}_{5} \mathrm{H}_{10} \mathrm{NH}$, THF, $74 \%$; (c) $\mathrm{C}_{5} \mathrm{H}_{10} \mathrm{NH}$, THF, $60 \%$; (d) silica gel, $\mathrm{MeOH}, 30$ days, $40 \%$. 


\section{Cytotoxicity}

Some acetylated fluorinated hexosamines (HexN), including peracetates of the $\alpha$-methyl glycoside of 3-fluoro-D-ManNAc [18], 3-fluoro-D-GlcNAc 5 [18], 4-fluoro-D-GlcNAc 1 [19], 4-fluoro-D-GalNAc 4 [19], 4,4-difluoro-D-xylo-HexNAc [19], and 4,6-difluoro-D-GalNAc [19] were reported to exhibit antiproliferative properties against L1210 leukemia cells in micromolar concentrations $\left(\mathrm{IC}_{50} 24-43 \mu \mathrm{M}\right)$. It was found that $O$-deacetylated amino sugars were often inactive due to low lipophilicity and poor cellular uptake [19]. Compound 5 was also cytotoxic to the human pancreatic cancer cell line KP1-NL $\left(\mathrm{IC}_{50}=30 \mu \mathrm{M}\right)$ [20], and $\mathbf{1}$ and its 1-O-deacetylated derivative 2 inhibited cell proliferation of the human prostate cancer cell line PC-3 ( $\mathrm{IC}_{50} 61 \mu \mathrm{M}$ for 2) [2]. Interestingly, while all 4-fluoro analogs 1-3 (Figure 1) reduced the expression of highly branched $\mathrm{N}$-glycans in PC-3 cells, the 6-O-deacetylated analog 3 showed only negligible cytotoxicity [2] implying that the inhibition of proliferation and perturbation of N-glycan biosynthesis occur by different mechanisms.

Increased cytotoxicity as a result of 1-O-deacylation was noted for a variety of acylated (nonfluorinated) D-mannosamine and D-glucosamine derivatives $[62,63]$. Acylated hexosamine derivatives were subsequently studied as possible templates for the development of anticancer therapeutics $[64,65]$. While the ability of hexosamine derivatives and analogs to inhibit cell growth creates an avenue for their use in the development of anticancer drugs, it also limits their utility as agents to modify the cellular glycome [62]. The cytotoxic activity of peracetylated monofluoro analogs 1, and 4-6, their 1-O-deacetylated derivatives $\mathbf{2}$, and $\mathbf{4 9 - 5 1}$, difluoro analogs $\mathbf{7}$ and $\mathbf{8}$, and oxazoline 41 was therefore tested for $24 \mathrm{~h}$ on the human prostate cancer
PC-3 cell line, and human ovarian cancer A2780 cell line using the MTT assay, and the obtained $\mathrm{IC}_{50}$ values were compared with those obtained for cisplatin and 5-fluorouracil.

All of the tested compounds induced only moderate to weak inhibition of $\mathrm{A} 2780$ cell proliferation $\left(\mathrm{IC}_{50}\right.$ values ranging from $78 \mu \mathrm{M}$ to $327 \mu \mathrm{M}$, Table 2) in comparison to cisplatin $\left(\mathrm{IC}_{50} 12.9 \mu \mathrm{M}\right)$. Anomeric deacetylation resulted in a higher activity in the case of 3 -fluoro-D-GlcNAc $\left(49, \mathrm{IC}_{50} 84 \mu \mathrm{M}\right.$, Table 2, entry 6), and especially 4-fluoro-D-GlcNAc (2, $\mathrm{IC}_{50} 78 \mu \mathrm{M}$, ca. 4-fold higher activity than that of the peracetylated 1, Table 2, entries 1 and 2), while 1-O-deacetylated $\mathbf{5 0}$ had a lower activity $\left(\mathrm{IC}_{50} 142 \mu \mathrm{M}\right.$, Table 2 , entry 4$)$ then the parent peracetate $4\left(\mathrm{IC}_{50} 78 \mu \mathrm{M}\right.$, Table 2 , entry 2$)$. All of the tested fluorinated D-glucosamine analogs also induced only weak inhibition on PC-3 cells ( IC $_{50}$ ranging from $134 \mu \mathrm{M}$ to $337 \mu \mathrm{M}$, Table 2, entries $1,2,5,6$, and 9), and 1-O-deacetylation seemed to have a negative effect here (Table 2, entries 2 and 6). On the other hand, the 1-O-deacetylated form of 3-fluoro-D-galactosamine 51 ( $\mathrm{IC}_{50} 28 \mu \mathrm{M}$, Table 2, entry 8) and 4-fluoro-Dgalactosamine $\mathbf{5 0}\left(\mathrm{IC}_{50} 54 \mu \mathrm{M}\right.$, Table 2, entry 4) reduced proliferation of PC-3 cells more than cisplatin $\left(\mathrm{IC}_{50} 182 \mu \mathrm{M}\right.$, Table 2, entry 12) and 5-fluorouracil ( $\mathrm{IC}_{50} 69 \mu \mathrm{M}$, Table 2, entry 13). The effect of anomeric deacetylation was particularly pronounced in 3-fluoro-D-galactosamine $\mathbf{5 1}$ owing to inactivity of the corresponding peracetate 6. Finally, difluoro analogs 7 and 8 , and oxazoline 41 exhibited weak (compound 7) to none (compounds 8 and 41) activity in the PC-cell line (Table 2, entries 9-11). Taken together, our results seem to corroborate in part the observations by Yarema at al. that the liberation of the anomeric hydroxy group in acylated hexosamines resulted in an enhancement

\begin{tabular}{|c|c|c|c|c|}
\hline entry & compd. no. & abbreviation $^{a}$ & PC-3 & A2780 \\
\hline 1 & 1 & $4 \mathrm{~F}-\mathrm{Ac}_{3} \mathrm{GlcNAc}$ & $235 \pm 26$ & $327 \pm 48$ \\
\hline 2 & 2 & $4 \mathrm{~F}-\mathrm{Ac}_{2} \mathrm{GlcNAc}-1-\mathrm{OH}$ & $337 \pm 36$ & $78 \pm 9$ \\
\hline 3 & 4 & $4 \mathrm{~F}-\mathrm{Ac}_{3} \mathrm{GalNAc}$ & $101 \pm 15$ & $78 \pm 9$ \\
\hline 4 & 50 & $4 \mathrm{~F}-\mathrm{Ac}_{2}$ GalNAc-1-OH & $54 \pm 5$ & $142 \pm 28$ \\
\hline 5 & 5 & $3 F-A_{3}$ GlcNAc & $134 \pm 17$ & $218 \pm 29$ \\
\hline 6 & 49 & $3 \mathrm{~F}-\mathrm{Ac}_{2} \mathrm{GlcNAc}-1-\mathrm{OH}$ & $308 \pm 38$ & $84 \pm 6$ \\
\hline 7 & 6 & $3 F-A_{3}$ GalNAc & $>500$ & $249 \pm 36$ \\
\hline 8 & 51 & $3 \mathrm{~F}-\mathrm{Ac}_{2}$ GalNAc-1-OH & $28 \pm 3$ & $137 \pm 24$ \\
\hline 9 & 7 & $3 \mathrm{~F}, 4 \mathrm{~F}-\mathrm{Ac}_{2} \mathrm{GlcNAc}$ & $199 \pm 34$ & $183 \pm 26$ \\
\hline 10 & 8 & $3 \mathrm{~F}, 4 \mathrm{~F}-\mathrm{Ac}_{2} \mathrm{GalNAc}$ & $>500$ & $250 \pm 41$ \\
\hline 11 & 41 & $3 \mathrm{~F}-\mathrm{Ac}_{2} \mathrm{Glc}-1,2$-oxazoline & $>1000$ & $108 \pm 14$ \\
\hline 12 & cisplatin & & $182 \pm 13$ & $12.9 \pm 1.5$ \\
\hline 13 & 5-fluorouracil & & $69 \pm 6$ & $52 \pm 7$ \\
\hline
\end{tabular}

'These abbreviations are provided for quick orientation, anomeric deacetylation is indicated by '-1-OH'. 
of their cytotoxicity $[62,63]$. The effect of anomeric deacetylation was, however, found much more cell-line and substratespecific for our fluoro analogs than it was for acylated natural hexosamines [62].

\section{Conclusion}

We have developed a synthetic route for the preparation of a series of 3- and 4-deoxofluorinated analogs of D-glucosamine and D-galactosamine. The choice of O-benzylated-1,6:2,3-dianhydro- $\beta$-D-mannopyranose $\mathbf{1 0}$ and 2,3-isopropylidene-Dmannosan $\mathbf{1 6}$ as starting material permits regio- and stereoselective introduction of both fluorine and nitrogen (as an azide) by nucleophilic substitution before acetolysis of the 1,6-anhydro bridge. The characteristic feature of the synthesis is the introduction of fluorine at C-3 by the reaction of D-gluco-configured 3-hydroxy derivatives with DAST with retention of configuration. The 1-O-deacetylated 3-fluoro and 4-fluoro analogs 51 and $\mathbf{5 0}$ of acetylated D-galactosamine were shown to be more cytotoxic in the PC-3 cell line than cisplatin and 5-fluorouracil. Most of the other fluoro analogs displayed moderate to low cytotoxicity. Fluoro analogs $\mathbf{6}-\mathbf{8}$ are new compounds and their influence on the cell-surface glycan biosynthesis is currently being studied. We anticipate that 1,6-anhydro-2-azido-fluorohydrins 20, 21, 26 and 31 will find use as building blocks for the synthesis of fluorinated oligosaccharides and other glycoconjugates because they can be immediately employed as glycosyl acceptors or readily converted into glycosyl donors. Research in this way is now in progress in our laboratory.

\section{Supporting Information}

\section{Supporting Information File 1}

Experimental procedures for compounds 1, 2, 4-8, 12, 18-22, 25, 26, 28, 29, 31, 40-42, 44, 45, and 48-51, HRMS results for reaction of $\mathbf{5 1}$ with piperidine, cell culture conditions and MTT assay, crystallographic data for compounds $25,28,29$, and 41 , and dose-response curves. [http://www.beilstein-journals.org/bjoc/content/ supplementary/1860-5397-12-75-S1.pdf]

\section{Supporting Information File 2}

NMR spectra for compounds $1,2,4-8,12,18-22,25,26$,

$28,29,31,40-46$, and $48-51$.

[http://www.beilstein-journals.org/bjoc/content/ supplementary/1860-5397-12-75-S2.pdf]

\section{Acknowledgements}

This work was supported by the project MEYS - NPS I LO1413 and MH CZ-DRO (MMCI, 00209805) and The Czech Science Foundation (grant No. 15-11223S).

\section{References}

1. Taylor, M. E.; Drickamer, K. Introduction to glycobiology, 3rd ed.; Oxford University Press: Oxford, United Kingdom, 2011.

2. Nishimura, S.-I.; Hato, M.; Hyugaji, S.; Feng, F.; Amano, M. Angew. Chem., Int. Ed. 2012, 51, 3386-3390. doi:10.1002/anie.201108742

3. Van Wijk, X. M.; Lawrence, R.; Thijssen, V. L.; van den Broek, S. A.; Troost, R.; van Scherpenzeel, M.; Naidu, N.; Oosterhof, A.; Griffioen, A. W.; Lefeber, D. J.; van Delft, F. L.; van Kuppevelt, T. H. FASEB J. 2015, 29, 2993-3002. doi:10.1096/fj.14-264226

4. Li, Y.; Zhou, Y.; Ma, Y.; Li, X. Carbohydr. Res. 2011, 346, 1714-1720. doi:10.1016/j.carres.2011.05.024

5. Frantom, P. A.; Coward, J. K.; Blanchard, J. S. J. Am. Chem. Soc. 2010, 132, 6626-6627. doi:10.1021/ja101231a

6. Pouilly, S.; Bourgeaux, V.; Piller, F.; Piller, V. ACS Chem. Biol. 2012, 7, 753-760. doi:10.1021/cb200511t

7. Hartman, M. C. T.; Coward, J. K. J. Am. Chem. Soc. 2002, 124, 10036-10053. doi:10.1021/ja0127234

8. Oberbillig, T.; Mersch, C.; Wagner, S.; Hoffmann-Röder, A. Chem. Commun. 2012, 48, 1487-1489. doi:10.1039/C1CC15139H

9. Hoffmann-Röder, A.; Kaiser, A.; Wagner, S.; Gaidzik, N.; Kowalczyk, D.; Westerlind, U.; Gerlitzki, B.; Schmitt, E.; Kunz, H. Angew. Chem., Int. Ed. 2010, 49, 8498-8503. doi:10.1002/anie.201003810

10. Barthel, S. R.; Antonopoulos, A.; Cedeno-Laurent, F.; Schaffer, L.; Hernandez, G.; Patil, S. A.; North, S. J.; Dell, A.; Matta, K. L.; Neelamegham, S.; Haslam, S. M.; Dimitroff, C. J. J. Biol. Chem. 2011, 286, 21717-21731. doi:10.1074/jbc.M110.194597

11. Marathe, D. D.; Buffone, A., Jr.; Chandrasekaran, E. V.; Xue, J.; Locke, R. D.; Nasirikenari, M.; Lau, J. T. Y.; Matta, K. L.; Neelamegham, S. Blood 2010, 115, 1303-1312. doi:10.1182/blood-2009-07-231480

12. Woynarowska, B.; Skrincosky, D. M.; Haag, A.; Sharma, M.; Matta, K.; Bernacki, R. J. J. Biol. Chem. 1994, 269, 22797-22803. http://www.jbc.org/content/269/36/22797.abstract

13. Woynarowska, B.; Dimitroff, C. J.; Sharma, M.; Matta, K. L.; Bernacki, R. J. Glycoconjugate J. 1996, 13, 663-674. doi:10.1007/BF00731455

14. Dimitroff, C. J.; Bernacki, R. J.; Sackstein, R. Blood 2003, 101, 602-610. doi:10.1182/blood-2002-06-1736

15. Dimitroff, C. J.; Kupper, T. S.; Sackstein, R. J. Clin. Invest. 2003, 112, 1008-1018. doi:10.1172/JCl19220

16. Cedeno-Laurent, F.; Opperman, M. J.; Barthel, S. R.; Hays, D.; Schatton, T.; Zhan, Q.; He, X.; Matta, K. L.; Supko, J. G.; Frank, M. H.; Murphy, G. F.; Dimitroff, C. J. J. Invest. Dermatol. 2012, 132, 410-420. doi:10.1038/jid.2011.335

17. Goon, S.; Bertozzi, C. R. J. Carbohydr. Chem. 2002, 21, 943-977. doi:10.1081/CAR-120016493

18. Sharma, M.; Bernacki, R. J.; Hillman, M. J.; Korytnyk, W. Carbohydr. Res. 1993, 240, 85-93. doi:10.1016/0008-6215(93)84174-5

19. Sharma, M.; Bernacki, R. J.; Paul, B.; Korytnyk, W. Carbohydr. Res. 1990, 198, 205-221. doi:10.1016/0008-6215(90)84293-4

20. Wasonga, G.; Tatara, Y.; Kakizaki, I.; Huang, X. J. Carbohydr. Chem. 2013, 32, 392-409. doi:10.1080/07328303.2013.815196

21. Arndt, S.; Hsieh-Wilson, L. C. Org. Lett. 2003, 5, 4179-4182. doi:10.1021/ol035606h

22. Černý, M.; Staněk, J., Jr. Adv. Carbohydr. Chem. Biochem. 1977, 34, 23-177. doi:10.1016/S0065-2318(08)60324-8 
23. Kulkarni, S. S.; Lee, J.-C.; Hung, S.-C. Curr. Org. Chem. 2004, 8 , 475-509. doi:10.2174/1385272043485800

24. Karban, J.; Sýkora, J.; Kroutil, J.; Císařová, I.; Padělková, Z.; Buděšínský, M. J. Org. Chem. 2010, 75, 3443-3446. doi:10.1021/jo1000912

25. Mtashobya, L.; Quiquempoix, L.; Linclau, B. J. Fluorine Chem. 2015, 171, 92-96. doi:10.1016/j.jluchem.2014.08.023

26. Kobayashi, K.; Kondo, T. Macromolecules 1997, 30, 6531-6535. doi:10.1021/ma970691s

27. Sarda, P.; Escribano, F. C.; Alves, R. J.; Olesker, A.; Lukacs, G. J. Carbohydr. Chem. 1989, 8, 115-123. doi:10.1080/07328308908047996

28. Faghih, R.; Escribano, F. C.; Castillon, S.; Garcia, J.; Lukacs, G.; Olesker, A.; Thang, T. T. J. Org. Chem. 1986, 51, 4558-4564. doi:10.1021/jo00374a013

29. Berkin, A.; Szarek, W. A.; Kisilevsky, R. Carbohydr. Res. 2000, 326, 250-263. doi:10.1016/S0008-6215(00)00049-5

30. Karban, J.; Horník, Š.; Červenková Št’astná, L.; Sýkora, J. Synlett 2014, 25, 1253-1256. doi:10.1055/s-0033-1341187

31. Hesek, D.; Lee, M.; Zhang, W.; Noll, B. C.; Mobashery, S. J. Am. Chem. Soc. 2009, 131, 5187-5193. doi:10.1021/ja808498m

32. Katavic, P. L.; Yong, K. W. L.; Herring, J. N.; Deseo, M. A.; Blanchfield, J. T.; Ferro, V.; Garson, M. J. Tetrahedron 2013, 69 , 8074-8079. doi:10.1016/j.tet.2013.06.079

33. Ganguli, A. R. S.; Coward, J. K. Tetrahedron: Asymmetry 2005, 16, 411-424. doi:10.1016/j.tetasy.2004.11.053

34. Trnka, T.; Černý, M. Collect. Czech. Chem. Commun. 1971, 36, 2216-2225. doi:10.1135/cccc19712216

35. Paulsen, H.; Stenzel, W. Chem. Ber. 1978, 111, 2348-2357. doi:10.1002/cber.19781110629

36. Karban, J.; Buděšínský, M.; Černý, M.; Trnka, T. Collect. Czech. Chem. Commun. 2001, 66, 799-819. doi:10.1135/cccc20010799

37. Rehnberg, N.; Magnusson, G. J. Org. Chem. 1990, 55, 5467-5476. doi:10.1021/jo00307a017

38. Doležalová, J.; Trnka, T.; Černý, M. Collect. Czech. Chem. Commun. 1982, 47, 2415-2422. doi:10.1135/cccc19822415

39. Karban, J.; Císařová, I.; Strašák, T.; Červenková Št’astná, L.; Sýkora, J. Org. Biomol. Chem. 2012, 10, 394-403. doi:10.1039/C1OB06336G

40. Paulsen, H.; Kolář, Č.; Stenzel, W. Chem. Ber. 1978, 111, 2358-2369. doi:10.1002/cber.19781110630

41. Oberdorfer, F.; Haeckel, R.; Lauer, G. Synthesis 1998, 201-206. doi:10.1055/s-1998-4484

42. Zottola, M. A.; Alonso, R.; Vite, G. D.; Fraser-Reid, B. J. Org. Chem. 1989, 54, 6123-6125. doi:10.1021/jo00287a029

43. Ogawa, S.; Nakamura, Y. Carbohydr. Res. 1992, 226, 79-89. doi:10.1016/0008-6215(92)84056-X

44. Hann, R. M.; Hudson, C. S. J. Am. Chem. Soc. 1942, 64, 925-928. doi:10.1021/ja01256a053

45. Staněk, J., Jr.; Černý, M. Synthesis 1972, 698-699. doi:10.1055/s-1972-21974

46. Ogawa, S.; Aso, D. Carbohydr. Res. 1993, 250, 177-184. doi:10.1016/0008-6215(93)84164-2

47. Wong, T. C.; Townsend, R. R.; Lee, Y. C. Carbohydr. Res. 1987, 170, 27-46. doi:10.1016/0008-6215(87)85003-6

48. Bernet, B.; Vasella, A. Helv. Chim. Acta 2007, 90, 1874-1888. doi:10.1002/hlca.200790196

49. Rönnols, J.; Manner, S.; Siegbahn, A.; Ellervik, U.; Widmalm, G. Org. Biomol. Chem. 2013, 11, 5465-5472. doi:10.1039/c3ob40991k
50. Karban, J.; Kroutil, J. Adv. Carbohydr. Chem. Biochem. 2006, 60, 27-101. doi:10.1016/S0065-2318(06)60003-6

51. Hale, K. J.; Hough, L.; Manaviazar, S.; Calabrese, A. Org. Lett. 2014, 16, 4838-4841. doi:10.1021/ol502193j

52. Hanessian, S.; Saavedra, O. M.; Vilchis-Reyes, M. A.; Llaguno-Rueda, A. M. Med. Chem. Commun. 2014, 5, 1166-1171. doi:10.1039/C4MD00072B

53. Hartlieb, S.; Günzel, A.; Gerardy-Schahn, R.; Münster-Kühnel, A. K.; Kirschning, A.; Dräger, G. Carbohydr. Res. 2008, 343, 2075-2082. doi:10.1016/j.carres.2008.02.003

54. Takahashi, Y.; Vasella, A. Helv. Chim. Acta 1992, 75, 1563-1571. doi:10.1002/hlca.19920750510

55. Mori, Y.; Morishima, N. Chem. Pharm. Bull. 1991, 39, 1088-1090. doi:10.1248/cpb.39.1088

56. Mori, Y.; Morishima, N. Bull. Chem. Soc. Jpn. 1994, 67, 236-241. doi:10.1246/bcsj.67.236

57. Kroutil, J.; Buděšínský, M. Carbohydr. Res. 2007, 342, 147-153. doi:10.1016/j.carres.2006.11.028

58. Zottola, M.; Rao, B. V.; Fraser-Reid, B. J. Chem. Soc., Chem. Commun. 1991, 969-970. doi:10.1039/c39910000969

59. Wray, V. J. Chem. Soc., Perkin Trans. 2 1976, 1598-1605. doi:10.1039/p29760001598

60. Rowell, R. M.; Feather, M. S. Carbohydr. Res. 1967, 4, 486-491. doi:10.1016/S0008-6215(00)81840-6

61. Avalos, M.; Babiano, R.; Cintas, P.; Jiménez, J. L.; Palacios, J. C.; Valencia, C. Tetrahedron Lett. 1993, 34, 1359-1362. doi:10.1016/S0040-4039(00)91795-7

62. Aich, U.; Campbell, C. T.; Elmouelhi, N.; Weier, C. A.; Sampathkumar, S.-G.; Choi, S. S.; Yarema, K. J. ACS Chem. Biol. 2008, 3, 230-240. doi:10.1021/cb7002708

63. Almaraz, R. T.; Aich, U.; Khanna, H. S.; Tan, E.; Bhattacharya, R.; Shah, S.; Yarema, K. J. Biotechnol. Bioeng. 2012, 109, 992-1006. doi:10.1002/bit.24363

64. Campbell, C. T.; Aich, U.; Weier, C. A.; Wang, J. J.; Choi, S. S.; Wen, M. M.; Maisel, K.; Sampathkumar, S.-G.; Yarema, K. J. J. Med. Chem. 2008, 51, 8135-8147. doi:10.1021/jm800873k

65. Elmouelhi, N.; Aich, U.; Paruchuri, V. D. P.; Meledeo, M. A.; Campbell, C. T.; Wang, J. J.; Srinivas, R.; Khanna, H. S.; Yarema, K. J. J. Med. Chem. 2009, 52, 2515-2530. doi:10.1021/jm801661m

\section{License and Terms}

This is an Open Access article under the terms of the Creative Commons Attribution License (http://creativecommons.org/licenses/by/2.0), which permits unrestricted use, distribution, and reproduction in any medium, provided the original work is properly cited.

The license is subject to the Beilstein Journal of Organic Chemistry terms and conditions: (http://www.beilstein-journals.org/bjoc)

The definitive version of this article is the electronic one which can be found at:

doi: $10.3762 /$ bjoc. 12.75 